\title{
PROFIL KETERAMPILAN GEOMETRI SISWA TUNANETRA DI SEKOLAH INKLUSI PADA MATERI SEGIEMPAT ( Studi Kasus di SMP MIS Surakarta )
}

\author{
Gigih Ardiantoro $^{1}$, Tri Atmojo Kusmayadi ${ }^{2}$ Riyadi $^{3}$ \\ ${ }^{1,2,3}$ Prodi Magister Pendidikan Matematika, FKIP Universitas Sebelas Maret Surakarta
}

\begin{abstract}
This research is aimed to describe the skills in geometry of visually impaired inclusion students on rectangular learning. This research was qualitative research. The research subjects were grade IX student of SMP MIS Surakarta. There were 3 students consisting of 1 low vision student, 1 totally blind when he was 15 years old, and 1 totally blind since she was born. The procedure of selecting the subject used in this research was purposive sampling technique. The data of research was collected through interviews based on rectangular task. The data was analyzed based the theory skill in Geometry's of Hoffer. The steps are : analyze all data are available from several sources, perform data reduction, compiling data in units, categorization the obtained data unit which shows each information on skill in Geometry of blind students in SMP MIS Surakarta as well as implementation of inclusion programs at SMP MIS Surakarta's data. Skill in Geometry's data was validated using time triangulation and implementation of inclusion programs at SMP MIS Surakarta's data was validated using sources triangulation. The result of this research show that: 1) skills in geometry of low vision student cannot reach level 2 at all;2) skills in geometry of student with totally blind when he was 15 year old can reach level 2 just on drawings skill. However, he cannot mastering level 0 on drawings skill well; 3) skills in geometry of student with totally blind since she was born cannot reach level 2 at all; 4) factors that affect skills in geometry of the students are availability of textbooks for students with visual impairment, the role of special guidances teachers, availability and uses of learning medium, teacher who has skills to handle student with visual impairment.

Keywords: Geometry, Skills in Geometry, Visually impaired Student, Inclusions Student, Rectangular
\end{abstract}

\section{PENDAHULUAN}

Pendidikan merupakan kebutuhan dasar setiap manusia untuk menjamin keberlangsungan hidupnya agar lebih bermartabat. Untuk itu setiap warga Negara Indonesia berhak mendapatkan pendidikan yang bermutu sesuai dengan bakat dan minatnya tanpa memandang perbedaan suku, ras, agama, status sosial, dan jenis kelamin. Hal ini dipertegas dalam UUD 1945 pasal 31 ayat 1, disebutkan bahwa tiap-tiap warga negara berhak mendapatkan pengajaran. Serta dalam Undang-undang RI nomor 20 tahun 2003 tentang sistem pendidikan nasional pasal 5 ayat 2 mengatakan bahwa warga Negara yang mempunyai kelainan fisik, emosional, intelektual, dan atau sosial berhak memperoleh pendidikan khusus. Hal ini berarti bahwa anak-anak yang memiliki gangguan visual juga berhak mendapat pendidikan khusus.

Dewasa ini, telah dikenal sistem pendidikan inklusif. Dalam Permendiknas nomor 70 tahun 2009 pasal 1, disebutkan definisi dari pendidikan inklusif adalah sistem penyelenggaraan pendidikan yang memberikan kesempatan kepada semua peserta didik 
yang memiliki kelainan dan memiliki potensi kecerdasan dan/atau bakat istimewa untuk mengikuti pendidikan atau pembelajaran dalam satu lingkungan pendidikan secara bersama-sama dengan peserta didik pada umumnya. Hal ini berarti bahwa siswa-siswa dengan gangguan visual dapat menempuh pendidikan di sekolah-sekolah umum dan tidak harus di sekolah khusus yang berarti pula bahwa beban belajar yang harus ditanggung oleh siswa tanpa gangguan visual harus menjadi tanggungan bagi siswa dengan gangguan visual.

Dalam buku standar isi yang diterbitkan oleh Badan Standar Nasional Pendidikan, mata pelajaran Matematika menjadi salah satu bagian dari struktur kurikulum untuk SMP dan geometri merupakan salah satu cabang dari matematika yang ada dalam kurikulum pendidikan matematika. Salah satu kompetensi dasar geometri yang harus dimiliki oleh setiap siswa SMP adalah mengidentifikasi sifat-sifat persegi panjang, persegi, trapesium, jajargenjang, belah ketupat dan layang-layang. Berdasarkan hasil pra survey yang dilakukan sekitar bulan mei 2015 oleh peneliti di SMP MIS Surakarta, siswa-siswa dengan gangguan visual yang menempuh pendidikan inklusi mendapatkan beban belajar yang sama dengan siswa regular. Dengan kata lain siswa dengan gangguan visual harus memiliki kompetensi dasar geometri tersebut.

Ketika seseorang yang mengalami gangguan visual diberi dua buah objek geometri yang berbentuk persegi dan persegi panjang, pertanyaan yang muncul adalah bagaimanakah orang tersebut mengidentifikasi mana yang merupakan persegi dan mana yang merupakan persegi panjang? Vianna et al. (2006) menyatakan "Geometry is usually regarded as an area of mathematics in which vision takes not only a fundamental, but also an essential role “. Penglihatan atau vision dianggap berperan penting dalam mempelajari geometri. Sementara itu, Emmanuel Giroux, seorang matematikawan yang mengalami kebutaan saat berusia sebelas tahun, menyatakan bahwa banyak matematikawan buta yang bekerja dalam geometri. Lalu ketika ia ditanya mengapa geometri, ia menjawab, “it's pure thinking” (Jackson, 2005:1249).

Rouzier et al. (2004) menyatakan, "Geometry is certainly one of the most difficult subjects to teach to blind pupils and one of the most useful at the same time...". Geometri merupakan salah satu mata pelajaran yang paling sulit untuk diajarkan kepada siswa buta dan salah satu yang paling berguna pada saat yang bersamaan.

Siswa dengan gangguan visual dalam bidang pendidikan luar biasa disebut sebagai tunanetra. Sedangkan siswa tanpa gangguan visual disebut dengan siswa awas. Tunanetra tidak hanya siswa yang mengalami kebutaan total, tetapi juga siswa yang mampu melihat tetapi sangat terbatas dan kurang dapat dimanfaatkan dalam kehidupan 
sehari-hari dan kegiatan belajar. Siswa dengan kondisi tersebut termasuk kedalam setengah melihat atau biasa disebut low vision (Sutjihati Somantri, 2007 :65).

Menurut Kohanova (2006:100-101), siswa tunanetra juga mampu menyelesaikan permasalahan matematika, meskipun pendekatan dalam menyelesaikan masalah tersebut sedikit berbeda dengan siswa tanpa gangguan visual. Selain itu siswa tunanetra mampu membedakan dan memberikan nama pada objek geometri datar dan geometri ruang, tetapi mereka kesulitan ketika diminta untuk mendeskripsikan tentang balok. Kadangkadang mereka menyebutnya sebagai persegi panjang. Selain itu, dalam mengeksplorasi suatu ruangan yang baru, siswa tunanetra menggunakan sentuhan sebagai alat analisis utama dan dibantu dengan indera pendengarannya. Baik siswa tunanetra maupun siswa awas mampu membuat model yang cukup tepat tentang ruang yang telah dieksplorasi. Dengan demikian sehubungan dengan representasi mental dari suatu ruang, siswa tunanetra memiliki kemampuan yang sama dengan siswa awas. Perbedaannya hanya cara untuk mendapatkan informasi tentang ruang tersebut.

Hoffer (1981) menyebutkan bahwa ada 5 kemampuan dasar yang harus dimiliki seorang siswa dalam mempelajari geometri, yaitu keterampilan visual (visual skill), keterampilan verbal (verbal skill), keterampilan menggambar (drawing skill), keterampilan logika (logical skill), dan keterampilan terapan (applied skill) (Dindyal, 2007:75). Keterampilan visual meliputi kemampuan untuk mengenal bermacam-macam bangun datar dan ruang, mengamati bagian-bagian dari sebuah bangun dan keterkaitan bagian satu dengan bagian yang lain, menunjukkan pusat simetri, sumbu simetri, dan bidang simetri dari sebuah gambar bangun, mengklasifikasikan bangun-bangun geometri menurut ciri-ciri teramati, menyimpulkan informasi lanjut berdasarkan pengamatan visual, dan memvisualisasikan model geometri, atau contoh-contoh penangkal yang dinyatakan secara implisit oleh data dalam suatu sistem matematika deduktif (Nur'aini Muhassanah, $2013: 19)$.

Perkembangan kognitif siswa tunanetra cenderung terhambat dibandingkan dengan siswa awas, hal ini karena pengenalan atau pengertian terhadap dunia luar tidak dapat diperoleh secara lengkap dan utuh. Akibatnya, pembentukan pengertian atau konsep terhadap rangsang atau objek yang berada di luar dirinya tidak diperoleh secara utuh. Hal ini disebabkan siswa tunanetra tidak memiliki kesan, persepsi, pengertian, ingatan, dan pemahaman yang bersifat visual terhadap objek yang diamati. Siswa tunanetra cenderung menggantikan indera penglihatan dengan indera pendengaran sebagai saluran utama penerima informasi yang mengakibatkan pembentukan pengertian atau konsep hanya berdasarkan pada suara atau bahasa lisan. 
Penelitian yang dilakukan oleh Vianna et al. (2006) dan beberapa guru yang ada di sekolah khusus dan sekolah inklusi di Rio de Janeiro. Dalam penelitiannya yang fokus pada pembelajaran tentang kesimetrian menunjukkan bahwa siswa tunanetra kesulitan dalam memahami kesimetrian apabila garis simetri berada di luar objek. Mereka tidak bisa fokus hanya pada gambar tetapi mereka juga harus melihat hubungannya dengan unsur-unsur lain yang membentuk bidang. Yang lebih sulit bagi mereka karena mereka harus memahami bahwa itu adalah bagian yang terputus yang bisa dihubungkan. Selain itu dinyatakan pula bahwa siswa tunanetra yang kehilangan kemampuan melihatnya ketika mereka tidak terlalu muda, mereka lebih bisa mengasosiasikan bentuk-bentuk dari objek-objek yang diberikan saat penelitian dengan bentuk yang mereka kenal ketika masih dapat melihat.

Selain kedua penelitian tersebut, sebuah esay yang ditulis oleh Klingenberg (2007) menyatakan bahwa siswa tunanetra butuh lebih banyak waktu untuk menguasai konsep-konsep geometri dan kemampuan geometri. Selain itu, dibutuhkan banyak penelitian untuk dapat memilih pembelajaran geometri yang baik bagi siswa tunanetra, baik yang buta total maupun low vision.

Berdasarkan paparan di atas peneliti tertarik untuk melakukan penelitian yang terkait pula dengan pembelajaran geometri pada siswa tunanetra. Penelitian ini bertujuan untuk : 1) mengetahui bagaimanakah keterampilan geometri siswa tunanetra baik buta total maupun low vision kelas IX SMP MIS Surakarta dalam menyelesaikan permasalahan yang berkaitan dengan segiempat, 2) mencari tahu faktor yang mempengaruhi keterampilan geometri siswa tunanetra baik buta total maupun low vision kelas IX SMP MIS Surakarta apabila masih kurang yang berkaitan dengan pelaksanaan inklusi.

\section{METODE PENELITIAN}

Penelitian ini merupakan penelitian kualitatif. Data dalam penelitian ini merupakan data deskriptif tentang keterampilan geometri siswa tunanetra di sekolah inklusi dalam materi segiempat serta faktor-faktor yang mempengaruhi keterampilan geometri siswa tersebut yang berkaitan dengan pelaksanaan inklusi.

Subjek dalam penelitian ini adalah tiga orang siswa tunanetra kelas IX di SMP MIS Surakarta. Masing-masing siswa mengalami kondisi tunanetra low vision (S1), buta total saat berusia 15 tahun (S2), dan buta total sejak lahir (S3). Subjek dalam penelitian ini dipilih secara purposive sampling, yaitu peneliti memilih subjek dengan kriteria 
tertentu. Subjek yang dipilih dalam penelitian ini adalah siswa tunanetra di sekolah inklusi yang berada dalam tingkatan kelas yang sama.

Pengumpulan data dilakukan dengan wawancara berbasis tugas. Peneliti membacakan pertanyaan yang ada pada lembar permasalahan kepada subjek. Peneliti meminta subjek menyelesaikan masalah pada lembar permasalahan yang dibacakan oleh peneliti sambil mengkomunikasikan apa yang ada dalam pemikirannya dan menanyakan beberapa hal terkait untuk mengungkap bagaimana keterampilan geometri subjek.

Untuk mengetahui faktor-faktor yang mempengaruhi keterampilan geometri siswa tunanetra di SMP MIS Surakarta, peneliti melakukan wawancara dengan guru pengajar matematika dan subjek penelitian. Wawancara dengan subjek penelitian dilaksanakan bersamaan dengan wawancara berbasis tugas.

Data yang telah terkumpul dianalisis dengan menggunakan analisis data nonstatistik karena penelitian ini merupakan penelitian kualitatif. Langkah-langkah analisis data terdiri dari menelaah seluruh data yang tersedia dari berbagai sumber, reduksi data, menyusun data dalam satuan-satuan, melakukan kategorisasi dari satuansatuan yang diperoleh, dan memeriksa keabsahan data. Pemeriksaan keabsahan data dilakukan dengan triangulasi. Data valid tentang keterampilan geometri siswa adalah data yang konsisten pada wawancara pertama dan kedua. Data yang tidak konsisten merupakan data yang tidak valid dan data tersebut tidak digunakan. Data valid tentang faktor-faktor yang mempengaruhi keterampilan geometri siswa tunanetra di SMP MIS Surakarta adalah data yang konsisten yang diperoleh dari guru dan siswa. Data yang tidak konsisten merupakan data yang tidak valid dan tidak digunakan. Setelah dilakukan analisis, data tersebut disajikan dan ditarik kesimpulan.

\section{HASIL PENELITIAN DAN PEMBAHASAN}

Berdasarkan analisis data, masing-masing siswa tunanetra kelas IX SMP MIS Surakarta mencapai tingkat berpikir geometri Van Hiele yang berbeda untuk tiap keterampilan geometri. Belum semua siswa tersebut dapat mencapai tingkat 2 dalam hal tingkat berpikir Van Hiele. Padahal menurut Van de Walle (2013) apabila siswa SMP ingin melanjutkan ke tingkat SMA dan belajar geometri secara deduktif maka siswa tersebut harus mencapai tingkat 2 untuk setiap pokok bahasan dalam geometri. Sehingga keterampilan geometri, khususnya pada materi segiempat, siswa tunanetra di SMP MIS Surakarta masih kurang.

Berdasarkan analisis data diperoleh keterampilan taktual untuk masing-masing siswa tunanetra kelas IX SMP MIS Surakarta dalam penelitian ini. Masing-masing siswa 
mencapai tingkat berpikir geometri Van Hiele yang berbeda-beda. Keterampilan taktual untuk siswa low vision kelas IX SMP MIS Surakarta hanya mencapai tingkat 0 saja. Hal ini ditunjukkan karena siswa tersebut hanya dapat memilih dengan tepat objek segiempat yang diminta berdasarkan penampilan bentuknya saja. Siswa low vision kelas IX SMP MIS Surakarta belum mengetahui sifat dari objek yang diberikan berkaitan simetri lipat suatu objek segiempat, selain itu siswa tersebut juga belum mengetahui dengan tepat bagaimana menentukan simetri lipat suatu objek segiempat yang diberikan. Siswa low vision kelas IX SMP MIS Surakarta belum dapat melihat keterkaitan antara dua objek potongan kertas yang diberikan hal tersebut dikarenakan siswa tersebut melihat suatu objek dari bentuk penampilannya saja.

Keterampilan taktual untuk siswa buta total saat berusia sekitar 15 tahun kelas IX SMP MIS Surakarta dapat mencapai tingkat 1. Siswa tersebut dapat memilih dengan tepat objek potongan kertas berbentuk segiempat yang diminta dengan cara meraba-raba dan juga mengetahui tentang sifat yang berkaitan dengan simetri lipat dari objek-objek yang diberikan. Namun demikian siswa tersebut masih belum dapat mengenali adanya keterkaitan antara dua objek segiempat yang diberikan hal ini dikarenakan siswa tersebut masih memandang sebuah objek tidak terkait dengan objek lain karena bentuknya berbeda.

Siswa kelas IX SMP MIS Surakarta yang mengalami buta total sejak lahir sangat kesulitan dalam hal keterampilan taktual untuk materi segiempat ini, bahkan dalam tingkat 0 sekalipun. Siswa tersebut belum mampu untuk memilih dengan tepat objek segiempat yang diminta. Siswa tersebut hanya mengandalkan rabaannya untuk memilih objek-objek yang diminta. Selain itu siswa tersebut juga belum mengetahui tentang sifatsifat yang berkaitan dengan simetri lipat dari objek segiempat yang diberikan. Siswa tersebut juga tidak mengenali keterkaitan antara dua objek segiempat yang diberikan

Berdasarkan analisis data, keterampilan verbal untuk masing-masing siswa tunanetra kelas IX SMP MIS Surakarta masih kurang. Ketiga siswa tersebut bahkan tidak dapat memenuhi tingkat 0 pada tingkat berpikir geometri Van Hiele. Keterampilan verbal siswa low vision kelas IX SMP MIS Surakarta sangat kurang. Siswa tersebut belum dapat menentukan semua nama segiempat yang bersesuaian dengan objek potongan kertas yang diberikan. Hal ini menunjukkan bahwa keterampilan verbal tingkat 0 untuk materi segiempat ini belum terpenuhi dengan baik. Selain itu siswa low vision kelas IX SMP MIS Surakart mendeskripsikan sifat-sifat dari objek segiempat yang diberikan hanya berdasarkan seperti apa bentuk fisik yang tampak dari objek tersebut. Siswa tersebut juga 
belum mampu untuk memberikan definisi yang tepat untuk sebuah objek segiempat yang diberikan.

Keterampilan verbal untuk siswa kelas IX SMP MIS Surakarta yang mengalami buta total pada usia 15 tahun juga sangat kurang. Keterampilan verbal tingkat 0 untuk materi segiempat ini juga belum dapat dipenuhi dengan baik oleh siswa tersebut. Hal ini ditunjukkan karena siswa tersebut tidak dapat menyebutkan semua nama segiempat dari objek yang diberikan dengan tepat. Siswa tersebut juga belum dapat mendeskripsikan dengan tepat tentang sifat-sifat dari objek segiempat yang diberikan. Selain itu siswa tersebut juga belum dapat memberikan definisi pada objek segiempat yang diberikan secara tepat.

Sama seperti kedua siswa tuannetra sebelumnya, siswa kelas IX SMP MIS yang mengalami buta total sejak lahir juga tidak mampu dalam keterampilan verbal tingkat 0 . Siswa tersebut belum dapat menentukan nama objek segiempat yang diberikan. Siswa tersebut juga tidak dapat mendeskripsikan dengan tepat sifat-sifat dari objek segiempat yang diberikan. Selain itu siswa tersebut juga belum dapat memberikan definisi yang tepat untuk objek segiempat yang diberikan.

Dari analisis data diperoleh informasi mengenai keterampilan menggambar dari siswa low vision, dan siswa buta total kelas IX SMP MIS Surakarta baik yang mengalami kebutaan sejak lahir maupun saat usia 15 tahun. Dalam penelitian ini ketiga siswa tersebut tidak dapat memenuhi tingkat 0 dari tingkat berpikir Van Hiele untuk keterampilan menggambar. Namun demikian ketiganya justru bisa memenuhi tingkat 1 dari tingkat berpikir Van Hiele pada keterampilan menggambar, bahkan siswa tunanetra buta total yang mengalami kebutaan saat usia 15 tahun dapat mencapai tingkat 2 .

Siswa low vision, dan siswa buta total kelas IX SMP MIS Surakarta baik yang mengalami kebutaan sejak lahir maupun saat usia 15 tahun dalam penelitian ini tidak dapat membuat bentuk segiempat yang diminta pada papan grid berpaku yang disediakan. Namun ketika ketiga siswa tersebut diberikan informasi tentang tentang suatu segiempat, ketiga siswa tersebut mampu membuat bentuk segiempat sesuai informasi yang diberikan. Ketiga siswa tunanetra kelas IX SMP MIS Surakarta juga dapat menunjukkan bagian dari objek yang dibangun sesuai dengan informasi yang diberikan.

Dalam keterampilan menggambar segiempat ini hanya siswa yang mengalami kebutaan total saat usia 15 tahun saja yang dapat memenuhi tingkat 2. Siswa tersebut dapat membangun objek lain yang berkaitan atau memiliki hubungan dengan objek yang diberikan sedangkan kedua siswa lainnya tidak dapat melakukannya. 
Berdasarkan analisis data diperoleh informasi siswa low vision dan siswa yang mengalami kebutaan sejak lahir keduanya tidak dapat memenuhi keterampilan logika tingkat 0 , tingkat 1 dan tingkat 2 . Kedua siswa tersebut tidak mampu memahami pengawetan bentuk dari objek segiempat yang diberikan serta tidak dapat memahami bahwa dua objek segiempat yang diberikan merupakan objek segiempat yang kongruen namun dengan posisi yang berbeda. Selain itu kedua siswa tersebut juga tidak dapat menggunakan sifat-sifat suatu kelas segiempat untuk menentukan apakah kelas segiempat tersebut terkandung dalam kelas segiempat yang lain atau tidak. Hal ini terjadi karena kedua siswa tersebut masih belum dapat memahami sifat-sifat dari segiempat yang diberikan dengan tepat. Kedua siswa tersebut juga masih belum dapat untuk menggunakan informasi-informasi yang diberikan untuk memperoleh informasi lainya tentang suatu objek segiempat.

Berbeda dengan kedua siswa sebelumnya, siswa yang mengalami kebutaan total saat berusia 15 tahun dapat memenuhi keterampilan logika tingkat 0. Siswa tersebut mampu memahami kekongruenan dari dua objek segiempat yang diletakkan dalam posisi berbeda serta memahami pengawetan bentuk dari objek segiempat yang diletakkan dengan posisi berbeda. Namun demikian, siswa yang mengalami kebutaan total saat berusia 15 tahun masih belum dapat mencapai tingkat 1 dan tingkat 2. Siswa tersebut masih belum dapat menggunakan sifat-sifat suatu kelas segiempat untuk menentukan apakah kelas segiempat tersebut terkandung dalam kelas segiempat lainnya atau tidak. Siswa tersebut juga belum dapat menggunakan informasi yang diberikan untuk memperoleh informasi lain yang berkaitan dengan sifat suatu objek segiempat yang diberikan.

Berdasarkan analisis data diperoleh informasi bahwa keterampilan terapan dari ketiga siswa tunanetra kelas IX SMP MIS Surakarta mampu mencapai tingkat 1. Ketiga siswa dapat mengidentifikasi objek-objek disekitarnya yang berbentuk segiempat serta dapat mengenali bentuk geometris dari objek fisik yang ada di sekitarnya. Namun demikian ketiga siswa masih belum dapat mencapai tingkat 2. Ketiga siswa tersebut belum dapat mamahami tentang model matematika yang mempresentasikan hubungan antara dua objek segiempat serta tidak memahami konsep tentang luas maksimal suatu objek segiempat yang dapat dibuat di dalam objek segiempat lainnya.

Beberapa faktor yang mempengaruhi keterampilan geometri siswa tunanetra kelas IX SMP MIS Surakarta dalam penelitian ini adalah tidak adanya buku pegangan khusus yang diterima oleh siswa inklusif tunanetra seperti dijelaskan pada bagian analisis data membuat siswa kurang dalam hal referensi untuk materi segiempat ini khusunya. 
Siswa tunanetra yang ada di SMP MIS Surakarta mendapatkan buku sama seperti buku yang diterima oleh teman-temannya yang awas. Hal ini tidak sesuai dengan apa yang disampaikan Abdul Salim Choiri (2009) bahwa pelaksanaan pembelajaran untuk pendidikan inklusif salah satunya yaitu dalam pelaksanaan pembelajaran, guru menggunakan media dan sumber belajar yang sesuai dengan kebutuhan peserta didik yang beragam. Hal ini berarti siswa tunanetra sebaiknya mendapatkan buku pegangan dengan huruf braile sehingga siswa tersebut dapat membaca isi buku.

Menurut Hoffer (1981) untuk dapat berhasil dalam mempelajari geometri, maka siswa harus dapat memiliki keterampilan geometri yang baik. Dengan semakin banyaknya referensi belajar yang bisa digunakan oleh siswa tunanetra, khususnya dalam materi geometri, diharapkan bisa meningkatkan keterampilan geometri siswa. Sehingga jika keterampilan geometri siswa meningkat maka siswa tersebut akan memiliki peluang lebih besar untuk berhasil dalam mempelajari geometri dan diharapkan dapat meningkatkan prestasi belajar matematikanya secara umum.

Dalam pelaksanaan inklusi di SMP MIS Surakarta, terdapat guru pembimbing khusus yang berasal dari guru di SLB YKAB Surakarta. Sesuai dengan analisis data yang telah dibahas sebelumnya, guru pembimbing khusus tersebut bertugas membacakan soal ulangan kepada siswa tunanetra yang ada di SMP MIS Surakarta. Peran guru pembimbing khusus ini masih kurang maksimal karena menurut Abdul Salim Choiri (2009), peran guru pembimbing khusus tidak hanya membacakan soal ulangan saja.

Terdapat beberapa media pembelajaran yang digunakan dalam KBM matematika khususnya pada materi segiempat. Salah satunya adalah papan grid berpaku. Namun media tersebut masih belum mampu untuk meningkatkan keterampilan menggambar siswa tunanetra. Berdasarkan analisis data yang telah dipaparkan sebelumnya, media tersebut jarang digunakan, sehingga keterampilan menggambar siswa menjadi kurang. Guru dan tenaga kependidikan lain pada satuan pendidikan penyelenggara pendidikan inklusif, wajib mendapatkan sosialisasi dan / atau pelatihan khusus tentang penyelenggaraan pendidikan inklusi. Tidak adanya pelatihan khusus akan berakibat guru tidak memiliki pengetahuan tentang bagaimana menangani siswa berkebutuhan khusus tunanetra khususnya terutama tentang bagaimana cara membelajarkan geometri kepada siswa tunanetra. Hal tersebut akan berakibat kurangnya keterampilan geometri siswa tunanetra.

Dengan adanya pelatihan khusus atau diklat untuk guru yang mengajar di sekolah inklusi diharapkan dapat memberi pengetahuan guru dalam menangani siswa tunanetra 
sehingga guru bisa mengambil langkah-langkah strategis dan efektif dalam membelajarkan geometri kepada siswa tuannetra.

\section{SIMPULAN DAN SARAN}

Pada keterampilan taktual, siswa low vision hanya mencapai tingkat 0 saja. Siswa tersebut dapat memilih objek segiempat yang diminta berdasarkan penampilan bentuknya saja. Siswa yang mengalami buta total saat berusia 15 tahun dapat mencapai tingkat 1 . Selain dapat menentukan segiempat yang diminta dengan meraba-raba, siswa tersebut juga mengetahui tentang sifat dari segiempat yang diberikan berkaitan dengan simetri lipatnya. Siswa yang mengalami buta total sejak lahir masih belum dapat memnuhi tingkat 0 dengan baik. Siswa tersebut sangat mengandalkan rabaannya dalam memilih objek segiempat yang diminta. Namun demikian, siswa tersebut masih belum tepat dalam memilih objek segiempat yang diminta.

Pada keterampilan verbal, ketiga siswa tunanetra kelas IX SMP MIS Surakarta belum mampu memenuhi tingkat 0 dengan baik. Ketiga siswa tersebut belum dapat menentukan nama segiempat yang bersesuaian dengan objek yang diberikan. Selain itu, ketiga siswa tersebut belum dapat mendeskripsikan sifat-sifat serta belum dapat memberikan definisi yang tepat dari objek segiempat yang diberikan.

Pada keterampilan menggambar, siswa low vision dan siswa yang mengalami buta total sejak lahir belum dapat memenuhi tingkat 0 dengan baik tetapi dapat memenuhi tingkat 1 . Sedangkan siswa yang mengalami buta total saat usia 15 tahun belum dapat memenuhi tingkat 0 dengan baik tetapi dapat memenuhi tingkat 1 dan tingkat 2 .

Pada keterampilan logika, siswa low vision dan siswa yang mengalami buta total sejak lahir belum dapat memenuhi tingkat 0 dengan baik. Sedangkan siswa yang mengalami buta total saat berusia 15 tahun hanya mencapai tingkat 0 saja.

Pada keterampilan terapan, ketiga siswa tunanetra kelas IX SMP MIS Surakarta mencapai tingkat 1 saja. Ketiga siswa tersebut mampu mengidentifikasi objek-objek di sekitarnya yang berbentuk segiempat serta mengenali bentuk geometris dari objek-objek fisik di sekitarnya.

Faktor-faktor yang mempengaruhi keterampilan geometri siswa inklusif tunanetra di SMP MIS Surakarta berkaitan dengan pelaksanaan inklusi di sekolah tersebut: 1) Ketersediaan buku pegangan khusus untuk siswa tunanetra; 2) Peran guru pembimbing khusus; 3) Ketersediaan dan penggunaan media pembelajaran; 4) Tenaga pengajar yang memiliki keterampilan dalam menangani siswa berkebutuhan khusus.

Saran yang dapat diberikan berdasakan hasil dari penelitian ini adalah : 1) Bagi siswa tunanetra diharapkan mampu lebih kreatif dalam menyelesaikan permasalahan- 
permasalahan geometri khususnya pada segiempat dan tidak hanya mengandalkan rabaan saja. Mengingat keterbatasan dalam visual, siswa dapat lebih menggunakan logika dalam menyelesaikan permasalahan dan menggunakan informasi-informasi yang diperoleh untuk mencari informasi lain dalam rangka menyelesaikan permasalahan. Sebagai contoh, misal siswa tunanetra diberikan sebuah objek segiempat. Siswa dapat menggunakan tali untuk mengukur panjang sisi-sisi objek tersebut. Misalkan ternyata setiap sisinya memiliki panjang yang sama, kemudian siswa dapat memeriksa banyaknya simetri lipat objek tersebut dan ternyata misalkan objek tersebut memiliki empat simetri lipat, maka siswa tersebut dapat menentukan bahwa objek tersebut berbentuk persegi. Selain itu diharapkan siswa tunanetra lebih sering berlatih dalam membangun objek atau membuat sketsa objek dengan alat-alat yang sesuai dengan keadaan siswa tunanetra; 2) Guru diharapkan dapat memberikan strategi mengajar geometri yang efektif untuk siswa tunanetra. Selain itu, jika diperlukan, guru memberikan pendampingan khusus untuk siswa tunanetra di luar jam pelajaran mengingat siswa tunanetra memerlukan perhatian khusus. Guru juga diharapkan untuk lebih kreatif dalam membelajarkan geometri kepada siswa tunanetra dan memaksimalkan sumber daya yang ada di sekolah untuk menunjang kegiatan pembalajaran matematika dan geometri pada khususnya. Selain itu sebaiknya guru juga memberi bekal kepada siswa tunanetra untuk berpikir kreatif dalam memecahkan permasalahan mengingat kekurangan yang mereka miliki; 3) Perlu adanya pelatihan untuk guru-guru di sekolah inklusi sehingga diharapkan guru-guru tersebut memiliki keterampilan dalam menangani siswa tunanetra. Dengan demikian guru bisa menentukan strategi mengajar geometri yang efektif bagi siswa tunanetra; 4) Untuk pemerintah diharapkan untuk dapat memberikan bantuan buku khusus untuk siswa tunanetra sehingga mereka tidak kesulitan dalam membaca konten yang ada dalam buku; 5) Bagi peneliti lainnya, hasil penelitian ini dapat sebagai acuan untuk membuat penelitian pengembangan baik media pembelajaran maupun model pembelajaran yang dapat meningkatkan keterampilan geometri siswa inklusi tunanetra atau mengadakan penelitian yang mengungkap faktor internal dari siswa tunanetra yang mempengaruhi keterampilan geometri.

\section{DAFTAR PUSTAKA}

Abdul Salim Choiri. 2009. Pendidikan Anak Berkebutuhan Khusus Secara Inklusif. Surakarta : Yuma Pustaka.

Badan Standar Nasional Pendidikan. 2006. Buku Standar Isi untuk SMP (Versi PDF). https://masdwijanto.files.wordpress.com/2011/03/buku-standar-isismp.pdf. diakses pada tanggal 1 Maret 2015. 
Hoffer, A. 1981. Geometry Is More Than Proof. National Council of Teacher of Mathematics Journal, Vol 74, No. 1, page 11-18.

Jackson, A. 2002. The World of Blind Mathematicians. Notices of the AMS, Vol 49, No. 10, page 1246-1251. www.ams.org/notices/200210/commmorin.pdf. diakses pada tanggal 3 Maret 2015.

Klingenberg, O. G. 2007. Geometry: Educational implications for children with visual impairment. Philosophy of Mathematics Education Journal. Vol 20, page 1-15. http://people.exeter.ac.uk/PErnest/ diakses pada tanggal 2 April 2015.

Kohanova, I. 2006. Teaching Mathematics to Non-Sighted Student: With Specialization in Solid Geometry. Thesis. Comenius University Bratislava.

Nur'aini Muhassanah. 2013. Analisis Keterampilan Geometri Siswa Dalam Memecahkan Masalah Geometri Berdasarkan Tingkat Berpikir Van Hiele. Tesis. Surakarta : UNS.

Rouzier, S., Hennion, B. and Segovia, T.P. 2004. Touching Geometry for Visually Impaired Pupils, page 104-109. In Denis Chene (edt). Proceedings EuroHaptics 2004. http://www.eurohaptics.vision.ee.ethz.ch/2004/38f.pdf. diakses pada 6 Maret 2015.

Salinan UU No. 20 tahun 2003. http://kemenag.go.id/file/dokumen/UU2003.pdf. Diakses pada tanggal 26 Februari 2015.

Salinan Permendiknas No.70 Tahun 2009. http://www.kopertis12.or.id/wpcontent/uploads/2013/07/Permen-No.-70-2009-tentang-pendidiian-

inklusif-memiliki-kelainan-kecerdasan.pdf. Diakses pada tanggal 25 Februari 2015.

Sutjihati Somantri. 2007. Psikologi Anak Luar Biasa. Bandung: PT Rafika Aditama.

UUD 1945 Amandemen ke-4. http://www.mahkamahkonstitusi.go.id/public /content/profil/kedudukan/UUD_1945_Perubahan\%204.pdf. Diakses pada tanggal 26 Februari 2015.

Van De Walle. 2013. Elementary and Middle School Mathematics Teaching Developmentally $8^{\text {th }}$ Editions. New Jersey : Pearson.

Viana, C.S., Barbosa, P.M., Rocha, D.F. and Silva, B. 2006. Teaching Geometry for Blind and Visually Impaired Students. File Topic Study Groups 2011 International Congress on Mathematical Education. tsg.icme11.org/document/get/715. Diakses tanggal 2 Maret 2015. 